\title{
Oral Ergotamine versus Theophylline as a Trial in Treatment of Low Tension Post Spinal Headache
}

\author{
SALLY E. SAKR, M.Sc.; SALAMA I. EL-HAWARY, M.D.; GHADA F. EL-BARADEY, M.D. and \\ MONA M. MOGAHED, M.D. \\ The Department of Anesthesiology \& Surgical Intensive Care, Faculty of Medicine, Tanta University, Tanta, Egypt
}

\begin{abstract}
Background: Spinal anesthesia with local anesthetic agents is extensively used. It provides excellent pain relief as compared to intravenous or epidural route. But spinal anesthesia has some complications; one of them is post spinal headache. Which may range from mild to severe, So there were many trials for treatment of this headache.
\end{abstract}

Aim: Our aim was to study the efficiency of oral ergotamine versus theophylline in treatment of low tension post spinal headache.

Material and Methods: This study was carried out on 90patient, 18-40 years, ASA I, scheduled for lower extremity and lower abdominal surgery under spinal anesthesia. Patients were randomized into three equal groups (30 patients in each group): Group 1: Patients received treatment in the form of (ergotamine $1 \mathrm{mg} / 8$ hours orally+ paracetamol $500 \mathrm{mg} / 8$ hours orally). Group 2 Patients received treatment in the form of (theophylline $250 \mathrm{mg}$ orally/8 hours+ paracetmaol $500 \mathrm{mg} / 8$ hours orally). Group 3 Patients received treatment in the form of (paracetamol $500 \mathrm{mg} / 8$ hours orally). The following parameters were compared between the 3 groups: Patients will be asked for headache evaluation in sitting position in the following times: Before medication, after 1 hour of medication then every 6 hours till complete resolution of headache, Onset of relieve of headache, Duration of treatment, Any side effects of each studied drugs and Patient satisfaction.

Results: As regard headache evaluation using Numerical rating scale (NRS), theophylline group showed significant decrease in NRS when compared to ergotamine group and paracetamol group. Also mean duration to complete pain relieve showed significant decrease in theophylline group when compared to ergotamine group and paracetamol group with more patient satisfaction while, as regard onset of pain relieve, ergotamine group showed significant decrease when compared to theophylline group and paracetamol group respectively. There were no side effects recorded in the three groups.

Conclusions: Adding either ergotamine or theophylline to paracetamol were more effective in decreasing intensity of PDPH pain than using paracetamol alone without side effects.

Correspondence to: Dr. Sally E. Sakr, The Department of Anesthesiology \& Surgical Intensive Care, Faculty of Medicine, Tanta University, Tanta, Egypt
In comparsion with ergotamine and paracetamol, theophylline was more effective due to lower Numerical rating scale, shorter duration till complete pain relieve with better patient satisfaction.

Key Words: Post dural puncture headache - ErgotamineThe ophylline - Paracetamol.

\section{Introduction}

ACCORDING to international headache society there are two types of headache, Primary headache as migraine, tension and cluster headache, and Secondary headache as extracranial, intra cranial, systemic disorders, drugs and toxins [1] .

Post dural puncture headache (PDPH) still remains a disabling complication of spinal anesthesia, and although enomerus progress have been made in understanding this clinical entity, including its epidemiology, pathophysiology, clinical symptoms, prevention, and treatment, however, this entity still needs further studies [2] .

Classic symptoms of PDPH consist of photophobia, nausea and vomiting, neck stiffness, tinnitus, diplopia, and dizziness, in addition to the often severe cephalgia [3]. The headache is usually severe and throbbing, frontal in origin, with radiation to occiput and is exacerbated by sitting or standing [4].

The positional nature of the headache and dramatic improvement on assuming the supine position remains the standard diagnostic criteria for this condition $[\mathbf{5 , 6 ]}$. The incidence of PDPH was reported to be $1-30 \%$ with $0 \%-14.5 \%$ incidence rate when small needles are used [7].

Treatment modalities for PDPH are over hydration, oral caffeine, ergotamine, theophylline, cor- 
ticotropin, subcutaneous sumatriptan, gabapentin, pregabalin, intramuscular adreno corticotropic hormone, intravenous (IV) hydrocortisone, epidural saline injection and epidural blood patches [8]

\section{Patients and Methods}

This prospective randomized controlled clinical study was done in Tanta University Hospitals durings 2018. It was performed on 90 patients scheduled for lower extremity and lower abdominal surgery under spinal anesthesia. The sample size was calculated using epi info software computer program created by center of disease prevention and control, version 2002. It was calculated as 30 patients for each study group

Written informed consent was provided by the patient himself. Each patient received explanation to the purpose of the study. All patients were identified by coded number to ensure privacy. Procedures were approved by both the institutional and the regional ethics committees. This study data was used only for scientific purpose.

\section{Inclusion critetria:}

ASA physical status, both sexes, age from 18 to 40 years old, patients with low tension PDPH diagnosed by post spinal frontal and or occipital discomfort worsened by upright posture and relieved by lying supine.

\section{Exclusion criteria:}

Patients with history of migraine or other type of headache, patients with history of previous intolerance to ergotamine or theophylline administration, patients with any unpredictable condition in surgery or any complication such as severe hypotension (whenever systolic blood pressure (SBP) was reduced more than $25 \%$ of base line) or with intraoperative vasopressor drug requirement, hypertensive or diabetic patients, smoker patients, patients with liver and renal disease,. patients with coronary artery disease.

\section{Consent:}

An informed written consent was taken from every patient included in this study after explanation of the risks and benefits of the procedure.

\section{Preoperative preparation:}

Monitoring: On arrival at the operation theatre, routine monitoring in the form of automated non invasive blood pressure, pulse oximetry, electrocardiogram were applied. A good venous access
(18 G. canula) was secured. And patient received $20 \mathrm{ml} / \mathrm{kg}$ normal saline $0.9 \%$ as preloading.

Equipment: Sterile towels and gauze packs, povidine iodine solution $10 \%, 27 \mathrm{G}$ hypodermic needles connected to syringes of Xylocaine $2 \%$ for the local anaesthetic skin infiltration, sterile gloves, 22G beveled tips Quincke spinal needles.

\section{Anesthetic technique:}

Positioning: Spinal anesthesia was performed in the sitting position. After standard draping, one of the L3-4 interspaces was chosen and the overlying skin was anesthetized by local infiltration with xylocaine $2 \%$. Lumber puncture was done in the midline using $22 \mathrm{G}$ beveled tip Quincke spinal needle. All patients received $3 \mathrm{ml}$ of hyperbaric bupivacaine $0.5 \%(15 \mathrm{mg})$. All patients were monitored for possibility of developing PDPH.

Classification: According to the drug used for treatment of PDPH, 90 patients were classified randomly into three equal groups (30 patients each) using sealed envelope technique to:

Group 1: Ergotamine group (GpE): (n=30 patients): Patients received treatment in the form of (erogotamine $1 \mathrm{mg} / 8$ hours orally + paracetamol $500 \mathrm{mg} / 8$ hours orally).

Group 2: Theophylline group (GpT): $(\mathrm{n}=30$ patients): Patients received treatment in the form of (theophylline $250 \mathrm{mg}$ orally/8 hours + paracetmaol 500mg/8 hours orally).

Group 3: Control group (Gp C): (n=30 patients): Patients received treatment in the form of paracetamol $500 \mathrm{mg} / 8$ hours orally.

\section{Measurements:}

1- Patients will be asked for headache evaluation in sitting position using $10 \mathrm{~cm}$ Numerical rating scale (NRS) with anchors of $0=$ no headache and $5=$ moderate and 10=worst headache imaginable in the following times: Before medication, after 1 hour of medication then every 6 hours till complete resolution of headache.

2- Onset of relieve of headache: It is the time from the onset of receiving the studied drug till the moment at which patient tolerate the sensation of headache.

3-Duration of treatment: It is the time passed from starting the treatment with studied drug till complete relieve of the headache diagnosed by patient remained for more than 30 minutes without headache and continues for 48 hours without medicaitons. 
4- Any side effects of each studied drugs.

5-Patient satisfaction: Patient was asked to the rate of relief the headache according to the following numerical scale: $0=$ unsuccessful. $1=$ Poor, $2=$ Moderate (headache required supplemental analgesia), $3=$ Good (little headache with no need of supplemental analgesia), 4= Excellent (no headache).

\section{Results}

There was no statistical significant difference between the three groups as regards to demographic data (age, sex and weight, ASA status and duration of surgery) (Table 1).

As regards to headache evaluation using $\mathrm{Nu}-$ merical rating scale (NRS), theophylline group showed significant decrease in NRS when compared to ergotamine group and paracetamol group (Table 2).

Table (1): Demographic data of the three studied groups.

\begin{tabular}{lllll}
\hline & $\begin{array}{c}\text { Group 1 } \\
\mathrm{N}=30\end{array}$ & $\begin{array}{c}\text { Group 2 } \\
\mathrm{N}=30\end{array}$ & $\begin{array}{l}\text { Group 3 } \\
\mathrm{N}=30\end{array}$ & $p$-value \\
\hline Age (years) & $26.43 \pm$ & $26.23 \pm$ & $26.25 \pm$ & 0.82 \\
& 3.32 & 3.41 & 4.51 & \\
Weight $(\mathrm{kg})$ & $79.60 \pm$ & $79.93 \pm$ & $78.63 \pm$ & 0.68 \\
& 3.04 & 3.08 & 4.08 & \\
Height $(\mathrm{cm})$ & $166.70 \pm$ & $166.73 \pm$ & $167.77 \pm$ & 0.97 \\
& 4.11 & 3.66 & 3.67 & \\
Duration & $49.23 \pm$ & $48.00 \pm$ & $50.40 \pm$ & 0.56 \\
of surgery & 7.76 & 8.53 & 8.53 & \\
\hline
\end{tabular}

$p$ - value significant if $<0.05$

Table (2): Mean Numerical rating scale value in the three groups.

\begin{tabular}{llll}
\hline & Group 1 & Group 2 & Group 3 \\
\hline Before & $5.2 \pm 1.69$ & $4.8 \pm 1.5$ & $5.66 \pm 2.09$ \\
$1 \mathrm{~h}$ & $3.5 \pm 1.40$ & $2.63 \pm 1.2$ & $4.8 \pm 1.95$ \\
$7 \mathrm{~h}$ & $2.93 \pm 1.46$ & $1.56 \pm 1.10$ & $4.03 \pm 2.15$ \\
$13 \mathrm{~h}$ & $2.3 \pm 1.3$ & $1 \pm 0.98$ & $3.77 \pm 1.6$ \\
$19 \mathrm{~h}$ & $1.85 \pm 1.199$ & $0.2 \pm 0.5$ & $2.99 \pm 1.63$ \\
$25 \mathrm{~h}$ & $1.58 \pm 0.19$ & 0 & $2.34 \pm 1.67$ \\
$31 \mathrm{~h}$ & $1.4 \pm 1.01$ & 0 & $2 \pm 1.4$ \\
$37 \mathrm{~h}$ & $1.1 \pm 0.80$ & 0 & $1.6 \pm 1.08$ \\
$43 \mathrm{~h}$ & $0.7 \pm 0.4$ & 0 & $1.06 \pm 1$. \\
$49 \mathrm{~h}$ & 0 & 0 & $0.8 \pm 1.07$ \\
$55 \mathrm{~h}$ & 0 & 0 & $1 \pm 0.63$ \\
$61 \mathrm{~h}$ & 0 & 0 & $0.8 \pm 0.4$ \\
$67 \mathrm{~h}$ & 0 & 0 & 0 \\
$p$. value & & 0.001 & \\
\hline
\end{tabular}

As regards to onset of pain relieve, ergotamine group showed significant decrease when compared to theophylline group and control group (Fig. 1).

As regards mean duration to complete pain relieve showed significant decrease in theophylline group when compared to ergotamine group and paracetamol group (Fig. 2).

As regards patient satisfaction showed significant increase in theophylline group when compared to ergotamine group and paracetamol group (Fig.3).

As regards side effects there was no significant difference between three groups.

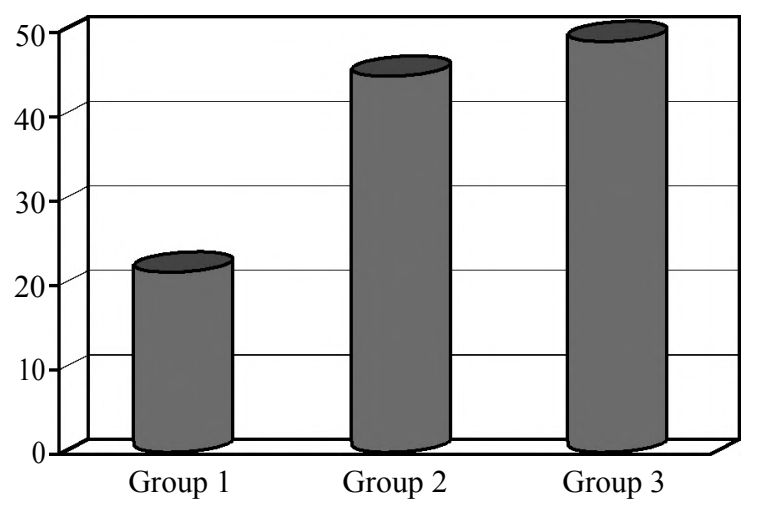

Fig. (1): Onset of relieve of headache between group 1, group 2 and group 3 .

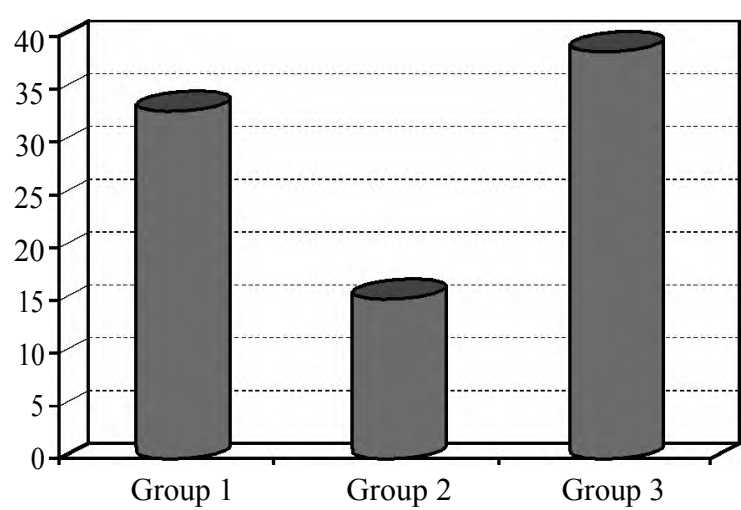

Fig. (2): Comparison of the duration of treatment in hours between group 1, group 2 and group 3 .

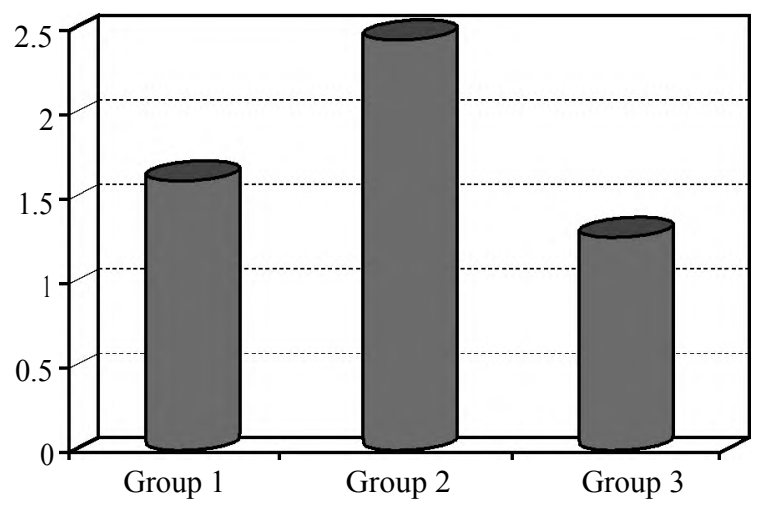

Fig. (3): Patient satisfaction. 


\section{Discussion}

Several invasive and non-invasive treatments were suggested for management of PDPH including medical therapy with non-steroidal analgesics, theophylline, morphine, ergotamine, or invasive procedures such as blood patch or caudal normal saline injection [9]

Our results showed as regards to headache evaluation using Numerical rating scale (NRS), theophylline group showed significant decrease in NRS when compared to ergotamine group and paracetamol group. Also mean duration to complete pain relieve showed significant decrease in theophylline group when compared to ergotamine group and paracetamol group with more patient satisfaction while, as regards to onset of pain relieve, ergotamine group showed significant decrease when compared to theophylline group and paracetamol group, there were no side effects recorded in the three groups.

In a study performed by Erol et al., [10] . caffine/ ergotamine compination was compared with gabapentin in 42 adult patients suffering from PDPH. Patients were asked to record the severity of their headache on NRS, results showed gabapentin group had less pain, compared to the caffine/ergotamine group. No patients withdrew, gabapentin and caffine lergotamine were well tolerated, and adverse events (somnolence, dizziness, tremor, and ataxia) did not occur [10].

To our knowledge there are few studies in using ergotamine in post spinal headache, but there are many studies in using ergotamine in migraine headache as following.

Ergotamine/Caffine were effective in migraine headache in a study performed by Suzanne et al., [11] and also in Sargen et al., [12].

In a study performed by Feuerstein et al., [13] on 11 patients with typical headache following diagnostic lumbar puncture the effect of oral treatment with theophylline was compared with that of placebo. When the headache was provoked by orthostatic strain, the six patients in the theophyllline group showed significantly less pain (mean pain score: $(16 \pm 3.91)$ than the five patients in the placebo group (mean pain score: $28 \pm 4.73$ ) [13].

In a study performed by Mahoori et al., [14] 60 patients with ASA physical status I who suffered from PDPH. Patients received theophylline tablet $250 \mathrm{mg}$ three times per day, and in the other group acetaminophen $500 \mathrm{mg}$ three times per day was administered. Pain intensity was assessed 2,6, and 12 hour after drug administration using NRS, results showed NRS values is significantly lower in theophylline group in comparison with the acetaminophen group at 2 hours $(55 \pm 1.57$ vs. 5.97 $\pm 1.27), 6$ hours ( $3.43 \pm 1.73$ vs. $4.33 \pm 1.49)$, and 12 hours $(2.67 \pm 2.35$ vs. $4.24 \pm 1.97)$ hours after drug administration $(p<0.05)$. No adverse effects were reported.

In a study performed by Sen et al., [15] forty patients with PDPH, whose surgeries were done under spinal anaesthesia, were selected randomly and divided into two groups of 20 each. One group received conservative treatment and the other group recieved theophylline $(400 \mathrm{mg}$ ) orally only. Intensity of headache was analysed using NRS of pain assessment immediately before $(0 \mathrm{~h})$ and at 8,16 and $24 \mathrm{th}$ hr of drug administration. Results showed significantly better relief of PDP in theophylline $(9.3 \pm 5.7)$ than the conservative group $(56.7 \pm 10.2)$ $(p<0.001)[15]$.

In a study performed by Aslakseni et al., [16] eight healthy male subjects volunteered for the study their ages were between 24 and 37 years (mean 32 years) and their body weights ranged from 67 to $104 \mathrm{~kg}$ (mean $80 \mathrm{~kg}$ ). The volunteers had no history of renal, gastrointestinal or hepatic disease, and their renal functions were normal as judged by the serum creatinine concentration. Haematological status and liver function tests were normal. The drugs given were two tablets of 125 mg microcrystalline theophylline and two tablets of $195 \mathrm{mg}$ aminophylline. A blood sample was taken from a catheter inserted into a forearm vein and the tablets were swallowed with $150 \mathrm{ml}$ water. Blood samples were then collected at $30 \mathrm{~min}, 1$, $2,3,4,6$, and $10 \mathrm{~h}$ both showing a reasonably rapid absorption phase with maximal serum concentrations after $2 \mathrm{~h}[\mathbf{1 6}]$

In Ergun's [17] study theophylline was administrated intravenous, but we have studied the efficacy of oral theophylline therapy in treatment of PDPH. The finding Ergun et al., reported that theophylline has beneficial effect in treating PDPH in comparsio with the placebo.

In a study performed byAlireza et al., [17] . on 90 patients who underwent elective orthopedic surgery under spinal anesthesia and experienced PDPH, patients received acetaminophen (group A), gabapentin (group B) and pregablin (group C). The mean Numerical rating scale score at the onset of headache (time 0 ), was $7.50 \pm 1.35$ in Group A, $8.03 \pm 1.60$ in Group B and 8.87 \pm 1.19 in Group C. 
Significant difference was observed between three groups $(p=0.001) .24 \mathrm{~h}$ after headache's onset $\mathrm{Nu}$ merical rating scale was significantly lower in Group C compared with B and in Group B compared with Group A $(p=0.001)$. The mean pain score, $48 \mathrm{~h}$ after the onset of headache was $3.07 \pm$ 1.37 in Group A, 2.47 \pm 1.13 in Group B and $0.87 \pm 0.73$ in Group $\mathrm{C}(p=0.001)$. The mean pain score, $72 \mathrm{~h}$ after headache's onset was $1.57 \pm 1.04$ in Group A, $1.03 \pm 0.18$ in Group B and 0.13 \pm 0.30 in Group C $(p=0.001)$ [18].

\section{Conclusion:}

Adding either ergotamine or theophylline to paracetamol were more effective in decreasing intensity of PDPH pain than using paracetamol alone without side effects. In comparsion with ergotamine and paracetamol, theophylline was more effective due to lower Numerical rating scale, shorter duration till complete pain relieve with better patient satisfaction.

\section{Conflicts of interest:}

No conflicts of interest declared.

\section{Authors' contributions:}

All authors had equal role in design, work, statistical analysis and manuscript writing.

\section{References}

1- AMORIM J.A., GOMES DE BARROS M.V. and VALENÇA M.M.: Post-dural (postlumbar) puncture headache: Risk Factors and Clinical Features. Cephalalgia, 32: 916-923. 2012.

2- BASURTO ONA X., MARTNEZ GARCA L., SOLÀ I. and BONFILL COSP X.: Drug therapy for treating postdural puncture headache. Cochrane. Database. Syst. Rev., 10: 78-87, 2011.

3- KUCZKOWSKI K.M.: The management of accidental dural puncture in pregnant women: What does an obstetrician need to know? Arch. Gynecol. Obstet., 275: 125$131,2007$.

4- NEPOMUCENO R. and HERD A.: Bilateral subdural hematoma after inadvertent dural puncture during epidural analgesia. J. Emerg. Med., 44: 227- 230, 2013.

5- STENDELL L., FOMSGAARD J.S. and OLSEN K.S.: There is room for improvement in the prevention and treatment of headache after lumbar puncture. Dan. Med. J., 59: 44-83, 2012.

6- KLEINE-BRÜGGENEY M., KRANKE P. and STAMER U.M.: Prophylaxis and therapy of postdural puncture headache A critical evaluation of treatment options. Anasthesiol. Intensiv. Med. Notfall. Med. Schmer-zther, 46: 516-524, 2011.

7- POUSKOULAS C.D., TAUB E. and RUPPEN W.: Successful treatment of postdural-puncture headache with surgical dura repair two years after spinal anesthesia. Cephalalgia., 33 (15): 1269-1271.

8- BASURTO ONA X., URIONA TUMA S.M., MARTi NEZ GARCiA L., SOLÁ I. and BONFILL COSP X.: Drug therapy for treating post-dural puncture headache. Cochrane. Database. Syst. Rev., 28: 792-794, 2013.

9- GAJRAJ N.M. PREGABALIN: Its pharmacology and use in pain management. Anesth. Analg., 105: 1805-1815, 2007.

10- EROL D.D.: The analgesic and antiemetic efficacy of gabapentin or ergotamine/caffeine for the treatment of postdural puncture headache. Advances in Medical Sciences, 56 (1): 25-29, 2011.

11- SUZANNE C., HARTMUT G., VALENTIN M., et al: The Rizatriptan-Ergotamine/Caffeine Preference Study Group, 15: 25-37, 1998.

12- SARGEN M., HUANG C.C., CHUANG C.C. et al.: The Journal of Head and Face Pain. 1998; 28(4): 263 - 266.

13-FEUERSTEIN T.J. and ZEIDES A.: Theophylline relieves headache following lumbar puncture. Placebo-controlled, double blind pilot study. Klinische Wochenschrift, 64 (5): $216-218,1986$

14- MAHOORI A., HASSANI E., NOROOZINIA H., et al.: Theophylline versus acetaminophen in the treatment of post-dural puncture headache (PDPH). Middle East Journal of Anesthesiology, 22 (3): 289-292, 2013.

15- SEN J. and SEN B.: Non invasive management of post dural puncture headache - a comparison. Bangladesh Journal of Medical Science, 13 (02): 114 -118, 2014.

16- ASLAKSENI A., BAKKE O.M. and VIGANDER M Comparative pharma-cokinetics of theophylline and Aminophylline in man Br. J. Clin. Pharmac., 11: 269-273, 1981.

17- ERGUN U., SAY B. and OZER G.: Intravenous theophylline decrease post dural puncture headache. J. Clinic. N. Eurosic., 15 (10): 1102 -1104, 2008.

18-ALIREZA M., HEYDAR N., et al.: Comparing the effect of pregabalin, gabapentin, and acetaminophen on postdural puncture headache .Saudi Journal of Anesthesia, 8: 357-377, 2014. 


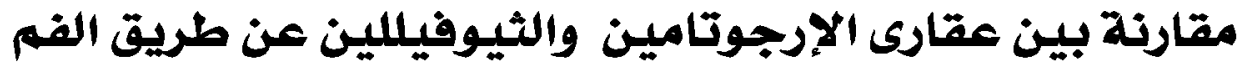

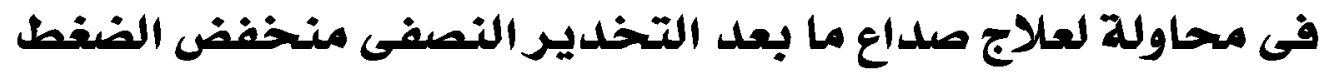

يعد المداع من أكثر المضاعفات المصاحبة للتخدير النصفى ، حيث أنه بنسبة تقارب الثلث فى المرضى الذين يخضعقف اللتذير النصفى، بحيث يكن ثلثهم تقريباً شديد الدرجة والثلث الآخر متوسط والثلث الثنات الأخير طفيف الدرجة.

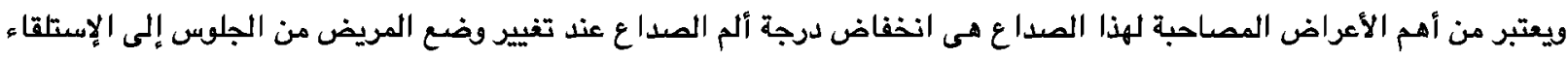
على الظهر بالأضافة إلى الأحساس بالغثيان والميل إلى القىء وهذا الصداع من النوع منخفض الضغط للسائل الشوكى. كما ظهرت العديد من المحاولات لعلاج هذا الصداع مثل عقار الكافيين، الثيوفلين والجابابنتين ومازال هناك العديد من المحاولات

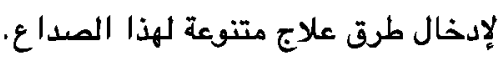
إن الهدف من هذه الدراسة هو تقييم كفاءة تناول الإرجوتامين مقارنة بالثيوفلين عن طريق إعطائهما بالفم لعلاج الصداع المصاحب اللتخدير النصفى.

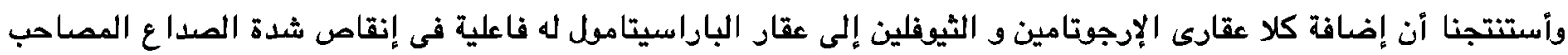

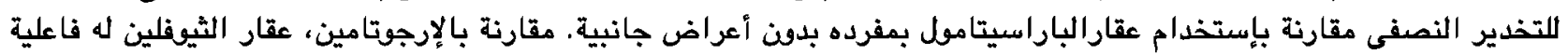

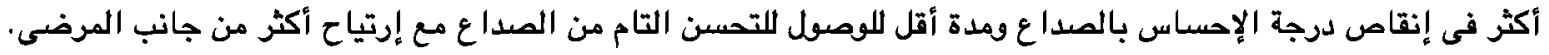

